\title{
Environmental factors affecting bee diversity in urban and remote grassland plots in Boulder, Colorado
}

\author{
Carol A. Kearns · Diana M. Oliveras
}

Received: 16 September 2008/ Accepted: 26 January 2009/Published online: 18 February 2009

(c) The Author(s) 2009. This article is published with open access at Springerlink.com

\begin{abstract}
Insects provide essential ecological services in both the natural environment and in human-dominated habitats. Because pollinator declines associated with land use change have been reported across the globe, there is great concern that pollinators and the ecosystem services they provide will be negatively affected. This study examines the diversity and abundance of bee pollinators in grasslands in Boulder County, Colorado, USA. Over five years, 5,200 bees were collected in grassland plots with different levels of urbanization. Most of the difference in species composition among three levels of urbanization was due to rare species that may not have been discovered in all plots. Neither the number of species nor their abundance differed significantly among the plot types, although the trend indicated increasing diversity with increasing distance from urbanization. Most notably, measures of urbanization, such as the amount of pavement and development, were not correlated with diversity. The most important factor affecting bee abundance, particularly for ground-nesting bees, was grazing regime. Bee abundance also was positively related to the number of flowering plant species. Other studies of different insects (grasshoppers and butterflies) in these plots showed results similar to ours. In contrast, previous studies on song-birds, raptors, and rodents showed significant differences between urban edge and remote plots in terms of organism abundance and diversity. Together, these results suggest that factors other
\end{abstract}

C. A. Kearns · D. M. Oliveras $(\bowtie)$

University of Colorado, Boulder, CO, USA

e-mail: Diana.Oliveras@colorado.edu

C. A. Kearns

Department of Biology, Santa Clara University, 500 El Camino Real, Santa Clara, CA 95053-0268, USA than the degree of urbanization are important in determining insect abundance and diversity.

Keywords Insects - Pollinators · Grasslands ·

Bee diversity · Bee abundance · Urbanization · Grazing

\section{Introduction}

Reports of pollinator declines around the globe have focused attention on the important roles that these organisms perform in natural biological communities and for humans (Buchmann and Nabhan 1996; Allen-Wardell et al. 1998; Kearns et al. 1998). Pollinators are responsible for fruit and seed production for $60-70 \%$ of flowering plants (Richards 1986). Seeds represent future generations of plants, and seeds and fruits provide food for numerous organisms. A major disruption in pollination services therefore could disrupt numerous communities. In addition, estimates suggest that pollinators are involved in the production of one-third of human food plants (Buchmann and Nabhan 1996). One cause of pollinator declines is the changing landscape caused by urban sprawl (Turner et al. 2004; Cane 2005a; Johnson and Klemens 2005a). Development of cities and suburbs results in habitat loss or habitat degradation (Johnson and Klemens 2005b). The loss or degradation of the landscape can eliminate or reduce the availability of resources necessary for pollinators to survive; thus, the new habitat can no longer support the original organisms (Johnson and Klemens 2005b). Urbanization also changes vegetation patterns such that previously unfragmented landscapes become a mosaic of pavement, buildings, parks, gardens, and small remnants of native habitat (French et al. 2005; Johnson and Klemens $2005 b$ ). For pollinators, urbanization means a change in the 
availability of nesting sites as well as the quality and accessibility of food plants, resources that must generally be located within close proximity to nest sites. Remnant fragments of natural habitat surrounded by development may be unable to support the original diversity of native pollinators or plants upon which they depend.

Studies have shown that community composition of varying arthropods can differ in response to urban land use (Bañkowska 1980, 1981; Kakutani et al. 1990; McIntyre et al. 2001). Recent studies have specifically addressed the bee fauna of urban habitats (Tomassi et al. 2004; Cane 2005b; Frankie et al. 2005; Zanette et al. 2005; Cane et al. 2006; McFrederick and LeBuhn 2006; Hinners 2008; Matteson et al. 2008). An analysis of data from several urban studies indicates that more than $90 \%$ of the individual bees collected belonged to only 12 common genera (Cane 2005b). It appears that some elements of the natural bee fauna disappear from urban habitats. Generalist bee species with broad tolerances are favored in urban areas (Cane 2005b), while specialists suffer from the absence of their host plants and decrease in number. These studies also indicate that cities can support diverse bee faunas, although the composition of plantings and the proximity to natural landscapes strongly affect that diversity. While some garden flowers are cultivated for showiness at the expense of nectar and pollen, others may be very attractive to pollinators. Plantings of native flowers often concentrate bee resources in a small area and can be a magnet for native pollinators (Frankie et al. 2002). Because bees are central foragers, bee diversity in urban areas may depend on the proximity of nesting sites and floral resources within their limited flight ranges (150-750 m for most solitary bees; Gathmann and Tscharntke 2002; Steffan-Dewenter et al. 2002; Cane 2005b). In addition, suitable patches of habitat must not be isolated from similar patches, or normal colonization and extinction may be disrupted, and small populations may ultimately collapse (Cane 2005b). There is evidence that rural open space, hedgerows, and undeveloped fields surrounding urban centers will help to maintain floral diversity and thereby augment bee diversity in urban habitats (Osborne et al. 1991; O’Toole 1993; Osborne and Corbet 1994; Steffan-Dewenter et al. 2002).

Boulder, Colorado, USA (latitude: $39^{\circ} 55^{\prime}-40^{\circ} 5^{\prime} \mathrm{N}$, longitude: $105^{\circ} 10^{\prime}-105^{\circ} 17^{\prime} \mathrm{W}$; elevation: $1,655 \mathrm{~m}$ ), where this research was conducted, is a city of 102,000 residents plus an additional 30,000 university students. The population of Boulder has increased by about 75,000 people in the last half century (Collinge et al. 2003), and human activities have dramatically changed the environment. The bee fauna may have changed as well. But unlike many cities, Boulder is surrounded by extensive public lands. Since 1868, when the first public land purchase was made by the residents of Boulder (City of Boulder Open Space and Mountain Parks 2006), undeveloped public lands have continued to expand and currently the City of Boulder Open Space and Mountain Parks manages over 43,000 acres of open space. Outside the city proper, Boulder County Open Space manages an additional 70,000 acres (Stewart 2005-2006) and the Boulder Ranger District manages 160,000 acres of National Forest (USDA 2007).

Changes in community composition related to urbanization in Boulder are known for many species of organisms. In 1994, Bock and Bock (1994) established a set of grassland biodiversity plots that have been used by various researchers to look for patterns of species composition associated with urbanization. Researchers using these plots have examined raptor (Berry et al. 1998), grasshopper (Craig et al. 1999), songbird (Haire et al. 2000), rodent (Bock et al. 2002), and butterfly (Collinge et al. 2003) communities. The vegetation of these plots has also been catalogued and plant species have been assigned importance indices based on percentage cover in the plots (Bennett 1997). The plots have been characterized as "urban" or "remote" and evaluated for multiple habitat characteristics (Haire et al. 2000). Urban plots bordered on areas of human activity (within $100 \mathrm{~m}$ ) and remote plots were surrounded by more natural habitat $(750 \mathrm{~m}$ and greater from development; Bock et al. 2002). Our study used a subset of these biodiversity plots plus four additional grassland plots to assess how native bees respond to different levels of urbanization, habitat fragmentation, vegetation changes, and other land use parameters. A future paper will evaluate dipteran pollinators in these plots.

Insect populations can be difficult to sample because of large spatial and temporal variability (Herrera 1988; Minckley et al. 1999; Cane and Tepedino 2001; Roubik 2001; Williams et al. 2001) but several researchers have had success in making comparisons of insect surveys among habitats sampled with the same techniques (Bañkowska 1980, 1981; Inoue et al. 1990; Kakutani et al. 1990; Kato et al. 1990; Hughes et al. 2000). This study uses the comparative approach and supplements comparisons among habitats with historical information.

It is often difficult to produce a complete species list of insects in a particular area. Compared to short sampling periods, longer sampling periods are likely to produce additional species that are uncommon, more difficult to collect, or have migrated into the area since sampling began (Magurran 2006). This study uses the program EstimateS (Colwell 2005) which calculates multiple measures of species richness and species diversity based on the pattern of species accumulation over multiple samples. 


\section{Hypotheses}

Our main hypothesis was that bee species richness and abundance would differ between urban and remote plots. In addition, we hypothesized that features of each plot, such as the extent of development and whether or not the plot was grazed, would also affect bee diversity. Urban and remote plots were expected to show differences in the proportions of ground-nesting and cavity-nesting bees, with ground-nesting bees dominating the remote sites.

\section{Methods}

Flower-visiting bees and flies were collected in 20 grassland biodiversity plots over the course of five summers from 2001 to 2005. In 2001, pollinator sampling was conducted in 16 Boulder Open Space biodiversity plots (Bock and Bock 1994). All plots were designated as remote or urban based on their proximity to urban development, roadways and urban parks. In addition, we recorded whether grazing by cattle was occurring in each plot. Each plot was marked with a central stake and GPS coordinates were recorded. Circular transects with a radius of $35 \mathrm{~m}$ from the central stake were marked with pin flags that remained in place for the field season. Sampling involved collecting all flower-visiting bees and flies in the circular transect with sweep nets within a standardized time frame. One researcher walked the perimeter and collected insects on flowers within an arm's length of either side of the circular transect. A second researcher sampled the interior of the plot. Each insect collected was given an accession number, field identification, and the flower species on which it was collected was recorded. Sampling was conducted during periods of peak bee activity from 10:00 am until 3:30 pm on sunny days with temperatures between 75 and $95^{\circ} \mathrm{C}$. Sampling took place in each plot once a week from mid-June to mid-August.

In 2002, four additional "Hayes" plots (named for the landowner) were added to the study. These additional plots were located on private property and used through a landowner agreement with Boulder Open Space. They were chosen because they were more isolated from development than the other remote plots, and the landowner had tried to maintain the habitat in a natural condition. None of these plots had been grazed by livestock within at least 20 years. In 2002 and 2003, all 20 plots were sampled as described above.

In 2004, plots were sampled with pan traps every 2 weeks in order to determine whether additional pollinator species were present that were not being collected on flowers. Three different colored pan traps [3.5-oz. Solo brand soufflé cups painted Bee Blue, Bee Yellow (Risk Reactor Paints), or left the original white] were set out in each plot for each sampling period (modified protocol from LeBuhn et al. 2003). Pans were filled $1 / 3$ full with a weak solution of soapy water. Bees and flies collected in pans were rinsed, blowdried, pinned, and given accession numbers. In 2005, plots were sampled by hand-netting in May and early June, since early-season samples were under-represented in previous years. In addition, eight gardens were sampled by handnetting and pan trapping as described above.

Bees were identified to genus when possible and sent to Robert Minckley at the University of Rochester for species (or morphospecies) identifications. Solitary bees were classified as ground nesting, cavity nesting or cleptoparasites. The percentages of ground-nesting and cavity-nesting bees were compared among plot types. Voucher specimens were placed in the University of Colorado Museum's entomology collection.

Habitat surrounding the 20 plots was characterized for two qualitative variables (urban or remote character and grazing regime) and seven quantitative environmental variables. Quantitative variables were measured for the 20 ha surrounding the central plot marker using Boulder Open Space vegetation maps and aerial photographs and tables (City of Boulder Open Space and Mountain Parks 2004), aerial photographs (USGS 1999) and ArcGIS (ESRI software 2004) mapping programs. The seven quantitative variables consisted of the number of square meters that were cultivated, developed, paved roads, grassland, urban park, water, and wetland. Additionally, the total number of plant species flowering in each plot, the mean number of species flowering over sampling periods for each plot, and the number of flowering species in that plot as determined by Bennett (1997) were recorded. Primarily wind-pollinated plants were not included in these measures.

\section{Data analysis}

For each plot, the number of species and number of handnetted bees were tallied by year for 2001-2003 and totaled over years. Pan trap data and data from early season samples in 2005 were used to add any potential pollinating species to the species list. Data analysis on those handtrapped bees identified to the species/morphospecies level was conducted using EstimateS 7.52 (Colwell 2005) and SAS 9.1 (SAS Institute Inc. 2002-2003). EstimateS is a statistical program that determines the true species richness in an area. Two species richness predictors were calculated: $\mathrm{ACE}$ and CHAO2. These statistics are based on abundance data rather than incidence data and as such are more appropriate for determining species richness of mobile organisms such as insects (Hellman and Fowler 1999; Brose and Martinez 2004). In addition, both Shannon and Simpson species diversity indices were calculated using 
SAS 9.1 for the following: each plot per year, each plot over the years 2001-2003 (full summers of hand-netting), all remote plots, all urban plots, all Hayes plots, all grazed plots, and all non-grazed plots.

Comparisons of abundance, species richness, and species diversity were made using SAS general linear models (Proc GLM). ACE and CHAO2 and abundance of non-Apis bees were $\log$ transformed to meet the assumptions of normality. Correlations between abundance, species richness, species diversity and environmental variables were made using Spearman's correlation coefficients (SAS Proc CORR). Raw abundance and relative proportions of ground and cavity-nesting solitary bees were analyzed for differences related to urbanization (SAS Proc GLM) and for correlations with environmental variables (SAS Proc CORR). Indices of similarity were calculated for urban, remote and Hayes plots.

\section{Results}

Over 2,100 bees were collected by hand-netting and 3,000 by pan-trapping in plots $(5,207$ specimens $)$ in 450 samples. Eighty-eight species were collected by hand-netting in the remote, urban and Hayes plots. Only two of these species were exclusive to the Hayes plots. Using EstimateS to predict the actual species richness, we arrived at predictors of 100.84 (ACE) and 98.98 (CHAO2; 91.94-118.58; 95\% confidence interval; Fig. 1). Sixteen additional species were collected in pan traps for a total of 104 grassland species. Five hundred and twenty bees were collected in gardens, adding four new species ("Appendix").

The index of similarity was 0.56 between the remote and urban plots, 0.41 between the remote and Hayes plots, and 0.44 between the urban and Hayes plots. Although it

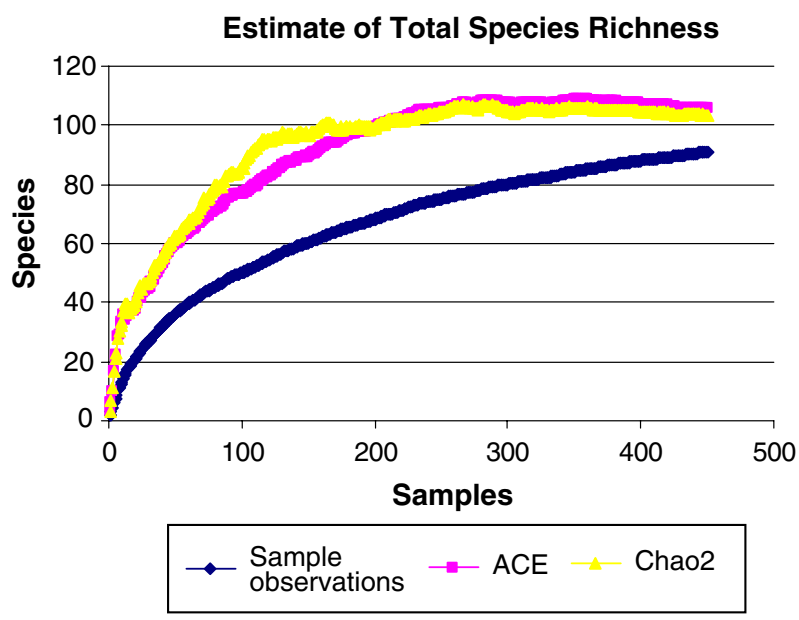

Fig. 1 Species richness of entire sample area including all plots, and based on hand-netted specimens appeared that each of the three types of plots have different community composition, most of the difference was due to species that existed in low abundance and may have been rare enough not to find in all plots. For example, of the 49 species that only occur in one plot type, the mean abundance was 1.48 individuals. Those species that were abundant in one plot type were also abundant in the other plot types. The most abundant species were generalists found in all plot types: Apis mellifera, Augochlorella striata, and Halictus ligatus. Halictus tripartitus and Lasioglossum (Dialictus) morphospecies 1 were abundant in remote and urban plots, and present in smaller numbers in Hayes plots. All of these species are eusocial bees. Some species of Lasioglossum (Dialictus) are eusocial as well.

Hand netting bees produced a total of 64 species of bees in the eight original remote plots, 62 species in urban plots, and 42 in the Hayes plots (Table 1). The number of species collected per plot did not differ among remote, urban and Hayes plots (SAS Proc GLM, $P=0.67$ ), nor did the abundance of bees (SAS Proc GLM, $P=0.74$ ). Estimates for true species richness and for species diversity did not differ significantly among urban, remote and Hayes plots (Table 1; ACE (log transformed for normality) $P=0.59$; Chao2 (log transformed for normality) $P=0.96$; Shannon index $P=0.82$; Simpson index $P=0.90$ ). The abundance of non-Apis bees did not differ among remote, urban, and Hayes plots (Proc GLM, $P=0.74$ ), nor did the abundance of Apis (SAS Proc GLM, $P=0.78$ ).

Environmental variables measured in the 20 ha surrounding each plot marker differed among remote, urban and Hayes plots (Table 2). In general, there was no correlation between measures of species richness, species diversity, bee abundance and these environmental variables. The correlation between the number of species in a plot and the amount of development was not significant (Spearman's correlation coefficient $-0.05, P=0.80$ ), nor was the correlation between abundance of non-Apis bees and development (Spearman's correlation coefficient $-0.20, P=0.39)$. There was, however, a significant negative correlation between the number of bee species and the amount of grassland in the 20 ha surrounding the central plot marker (Spearman correlation coefficient -0.45 , $P=0.05)$. In addition, bee diversity in plots was correlated with the mean number of species flowering in the plot over the course of sampling (Simpson index of bee diversity and flowers: Spearman correlation coefficient $0.45, P=0.04$; Shannon index of bee diversity and flowers: Spearman correlation coefficient $0.52, P=0.01$ ), as well as Bennett's value for the number of flowering species in the plot (Simpson index of bee diversity and Bennett value: Spearman correlation coefficient 0.57, $P=0.02$; Shannon index of bee diversity and Bennett value: Spearman correlation coefficient $0.53, P=0.04)$. 
Table 1 Comparison of hand-netted bee data from urban, remote and Hayes plots

\begin{tabular}{|c|c|c|c|c|}
\hline & Urban plots & Remote plots & Hayes plots & Sum of all plots \\
\hline Number of species & 62 & 64 & 42 & 91 \\
\hline $\mathrm{ACE}$ & 83.16 & 91.64 & 52.78 & 100.84 \\
\hline $\mathrm{CHAO}^{\mathrm{a}}$ & 74.59 (66.29-98.97) & $90.86(74.43-133.15)$ & $69.11(50.05-128.30)$ & 98.98 (91.94-118.58) \\
\hline Shannon index & 2.68 & 2.77 & 2.8 & 2.87 \\
\hline Simpson Index & 5.98 & 6 & 8.96 & 6.67 \\
\hline
\end{tabular}

Estimators calculated with EstimateS (Colwell 2005)

a $95 \%$ Confidence interval

Table 2 Plot variables

\begin{tabular}{|c|c|c|c|c|c|c|c|c|c|c|c|c|}
\hline Plot & $\begin{array}{l}\text { Plot } \\
\text { type }\end{array}$ & $\begin{array}{l}\text { Grazing } \\
\text { regime }\end{array}$ & $\begin{array}{l}\text { Cultivated } \\
\text { (sqm) }\end{array}$ & $\begin{array}{l}\text { Developed } \\
\text { (sqm) }\end{array}$ & $\begin{array}{l}\text { Highway } \\
\text { (sqm) }\end{array}$ & $\begin{array}{l}\text { Grass } \\
(\mathrm{sqm})\end{array}$ & $\begin{array}{l}\text { Park } \\
\text { (sqm) }\end{array}$ & $\begin{array}{l}\text { Water } \\
\text { (sqm) }\end{array}$ & $\begin{array}{l}\text { Wetland } \\
\text { (sqm) }\end{array}$ & $\begin{array}{l}\text { Bennett } \\
\text { flowers }\end{array}$ & $\begin{array}{l}\text { Recorded } \\
\text { flowers }\end{array}$ & $\begin{array}{l}\text { Mean } \\
\text { flowers }\end{array}$ \\
\hline 1 & Urban & Not & 0 & 156701.5 & 0 & 918,747 & 0 & 0 & 0 & 81 & 71 & 10.81 \\
\hline 2 & Urban & Notgrz & 0 & 6720.984 & 0 & $1,068,728$ & 0 & 0 & 0 & 74 & 52 & 8.46 \\
\hline 4 & Remote & Notgrz & 0 & 0 & 0 & $1,023,642$ & 0 & 0 & 51804.8 & 78 & 53 & 9.07 \\
\hline 5 & Remote & Notgrz & 28849.52 & 0 & 0 & $1,046,597$ & 0 & 0 & 0 & 76 & 52 & 9.22 \\
\hline 12 & Remote & 1 Year & 0 & 0 & 0 & $1,027,225$ & 0 & 0 & 48219.1 & 72 & 66 & 10.27 \\
\hline 13 & Remote & 1 Year & 0 & 0 & 0 & $1,015,450$ & 0 & 0 & 59993.9 & 80 & 76 & 12.4 \\
\hline 14 & Urban & 1 Year & 0 & 143543.5 & 0 & 166,468 & 429,763 & 335,669 & 0 & 73 & 63 & 9.11 \\
\hline 15 & Urban & 1 Year & 0 & 315596.4 & 0 & 660,606 & 41650.9 & 0 & 57591.7 & 81 & 63 & 9.92 \\
\hline 28 & Urban & Grazed & 0 & 247,237 & 0 & 806,886 & 21339.5 & 0 & 0 & 75 & 59 & 8.61 \\
\hline 29 & Urban & Grazed & 0 & 208953.8 & 0 & 750,737 & 107,928 & 0 & 7844.81 & 74 & 60 & 9.58 \\
\hline 46 & Remote & Notgrz & 0 & 0 & 21797.4 & 998,952 & 0 & 0 & 54711.4 & 41 & 51 & 9.27 \\
\hline 47 & Remote & Notgrz & 0 & 0 & 0 & 957,823 & 0 & 0 & 117,638 & 18 & 42 & 6.38 \\
\hline 58 & Urban & Notgrz & 639114.2 & 179163.7 & 0 & 257,187 & 0 & 0 & 0 & 39 & 41 & 7.76 \\
\hline 59 & Urban & Notgrz & 960394.4 & 2064.764 & 0 & 113,005 & 0 & 0 & 0 & 32 & 47 & 6.92 \\
\hline 60 & Remote & Grazed & 0 & 0 & 0 & $1,075,495$ & 0 & 0 & 0 & 58 & 48 & 8.42 \\
\hline 61 & Remote & Grazed & 0 & 0 & 0 & $1,075,499$ & 0 & 0 & 0 & 62 & 57 & 10.13 \\
\hline 67 & Hayes & Never & 0 & 0 & 0 & 932,866 & 0 & 0 & 142,601 & - & 47 & 8.47 \\
\hline 68 & Hayes & Never & 0 & 0 & 0 & 709,102 & 0 & 0 & 366,366 & - & 37 & 7.16 \\
\hline 69 & Hayes & Never & 0 & 0 & 0 & $1,075,499$ & 0 & 0 & 0 & - & 51 & 10.74 \\
\hline 70 & Hayes & Never & 0 & 4779.153 & 0 & $1,056,893$ & 0 & 0 & 13796.7 & - & 47 & 11.05 \\
\hline
\end{tabular}

Sqm refers the number of square meters of that environmental variable found within the 20 ha surrounding the central plot marker Bennett flowers refers to the number of species of animal pollinated plants recorded in the plot by Bennett (1997)

Recorded flowers refers to the number of species of animal pollinated plants recorded over the course of our study

Mean flowers refers to the average number of species flowering within the plot on a sampling date

Two significant differences were detectable among plots under the four different grazing regimes [four grazing regimes: (1) Hayes plots not grazed for 20+ years; (2) plots not grazed during study; (3) plots grazed during 1 year of the study; (4) plots grazed throughout the study]. First, overall, the abundance of native bees was significantly different among the four different regimes (Proc GLM, $P=0.005$ on $\log$ transformed abundance variable). Abundance decreased with increased grazing. The mean number of bees collected per year was highest in plots that were not grazed (Hayes plots $27.13^{\mathrm{a}}$, plots not grazed during the study $27.53^{\mathrm{ab}}$ ). The number of bees decreased in plots with more grazing (means for plots grazed 1 year $15.25^{\mathrm{bc}}$, plots grazed over course of study $13.83^{\mathrm{c}}$ ) Superscripts represent Duncan groupings of the $\log$ transformed variables. Although bee abundance differed among grazing regimes, there were no significant differences in species richness.

The second difference among the four grazing regimes was in the number of plant species that were flowering (Proc GLM, $P=0.003$ ). Those plots that were grazed only 1 year during the course of the study had significantly more species flowering in that year of grazing (mean number of species flowering in plots grazed 1 year $67^{\mathrm{a}}$ ) compared to other grazing regimes (mean number of species flowering 
in Hayes plots $45.5^{\mathrm{b}}$; in plots not grazed during the study $51.13^{\mathrm{b}}$; in plots grazed throughout the study $56^{\mathrm{b}}$. Superscripts represent Duncan groupings.

We examined the relative abundance of ground-nesting and cavity-nesting solitary bee species in our plots. The percentage of ground-nesting bees was positively correlated with the amount of grassland within the 20 ha surrounding each central plot marker (Spearman correlation coefficient $0.55, P=0.011)$. The abundance of ground-nesting bees differed among remote, urban and Hayes plots $(P=0.06)$, with Hayes plots having the highest mean abundance of bee species (32.0), followed by remote plots (26.8) and then urban plots (17.0). The abundance of ground-nesting bees also differed among grazing regimens $(P=0.02)$. Plots grazed for 1 year had the highest mean abundance of ground-nesting bees (36.50) followed by the Hayes plots that had not been grazed in over 20 years (23.00). Routinely grazed plots had a mean abundance of 18.5 ground-nesting bees, and plots that had not been grazed during our study had a mean abundance of 16.25 bees. The abundance of cavity nesting bees was low at all sites, and the percentage of cavity nesting bees (arcsin transformed) was not significantly different among the remote, urban and Hayes plots, nor among different grazing regimes.

\section{Discussion}

The 108 bee species collected in this study compare favorably with the 116 species found in similar Boulder County habitats in 1907 (Cockerell 1907; analysis in Kearns and Oliveras, in preparation). Thus, Boulder County does not appear to have suffered significant losses in bee diversity despite the environmental and human population changes that have occurred in the past century. Although urban, remote, and Hayes plots differed in respect to environmental variables, all plot types were species-rich. Comparable measures of ACE and CHAO2 within plot types increase our confidence in these values. EstimateS indicated that all plot types were likely to contain additional species, especially the remote and Hayes plots. Both Shannon and Simpson species diversity indices suggest that diversity increased from urban plots to remote plots to Hayes plots as we anticipated, but differences in overall abundance and species richness were not dramatic and did not follow predicted patterns.

In some of the earlier studies conducted in the Bock biodiversity plots, species composition changed dramatically between urban edges and remote plots. For example, Haire et al. (2000) found that grassland nesting songbirds decreased in abundance in more urban habitats. In contrast, robins, starlings, grackles, house finches and house sparrows were almost five times as abundant in urban edge plots as remote (interior) plots (Bock et al. 1995, 1999).
Another study of diurnal raptors in these plots demonstrated that 5-7\% urbanization was a critical threshold value that limited bald eagles, ferruginous hawks, rough-legged hawks and prairie falcons (Berry et al. 1998). In contrast, red-tailed hawks, Swainson's hawks and American kestrels were not sensitive to the amount of urbanization in the urban plots (Berry et al. 1998). For the most part, rodent studies in the biodiversity plots also showed that species composition differed between remote, interior areas and urban edges. Bock et al. (2002) showed that three species of native rodents were most abundant in remote plots; however, the non-native house mouse was found equally in both urban and remote plots.

Two studies of insects on these biodiversity plots showed results more consistent with our bee study. Craig et al. (1999) found that grasshopper populations were not seriously affected by urban development. Collinge et al. (2003) found that urbanization did not have a predictable effect on butterfly abundance or species richness. Perhaps because of their size and mobility, insects are responding to habitat changes at a different scale. Insects are influenced by habitat fragmentation associated with human land use, such that smaller fragments support fewer species (McGeoch and Chown 1997; Bolger et al. 2000; Collinge 2001; Hinners 2008). It is possible that small fragments are less likely to contain the resources that bees require, such as appropriate nesting sites, food, water, etc. Thus, bees, grasshoppers and butterflies might be more affected by the presence or absence of specific habitat features rather than direct effects of urbanization.

Surprisingly, there were few correlations between bee richness and the seven quantitative environmental variables for the area surrounding each plot. We had predicted that an increase in development would result in a decrease in species richness. Instead, we found no relationship between urban development and species richness. Our failure to find a correlation between development and species richness may be due to the differences in scale with which humans and insects perceive the environment. We were sampling in Open Space at the edge of development, and the area of developed land was measured for the 20 ha surrounding the center of the plot. However, bees typically fly short distances. They may have had all the resources they needed at the urban edge and may not have flown into the developed area. Alternatively, it is possible that the high prevalence of generalist species (A. mellifera, A. striata, and H. ligatus) in each of our plots weakened any effect that the environmental variables might have had. These species are not limited by a narrow range of suitable ecological factors; the plots may have contained a variety of resources that they could use, despite the varying levels of development as measured by our plot variables.

Grazing by cattle had effects on both bee abundance and on flowering. Plots that were routinely grazed had the lowest 
abundance of bees. Our Hayes plots (grazing regime 1), which had not been grazed in over 20 years, had the highest abundance of bees. The Hayes plots differed significantly from the plots that were grazed (grazing regimes 3 and 4). Thus, grazing alone may not have been the cause for this difference, since other aspects of the habitat were likely to be different in these more natural Hayes plots. Nonetheless, the plots that were not grazed during the course of this study (grazing regime 2) still had a higher abundance of bees than those plots that were grazed during the study. These results are similar to those of Kruess and Tscharntke (2002) who found that decreased grazing resulted in increased abundance of bees in grasslands in Germany. As in our study, species richness was not affected.

Flowering was also affected by grazing. The number of species flowering under the different grazing regimes was similar with one exception. Those plots that were grazed only 1 year of the study (grazing regime 3 ) had a greater number of species flowering each sampling period during that year of grazing. We believe that this is due to intermediate disturbance effects. A moderate disturbance by cattle during that 1 year of grazing may have reduced the dominant forms of vegetation and allowed other plant species to grow and flower. In comparison, there was no grazing in the Hayes plots or in the eight plots of grazing regime 2; the lower levels of disturbance in these plots may have precluded the establishment, growth, and flowering of new plant species that are more attractive to bees. Similarly, the decreased number of flowers in the plots that were grazed routinely (grazing regime 4) may be due to their consumption by cows.

The abundance of solitary ground-nesting bees differed among plot types as well as grazing regimes. The abundance of ground-nesting bees was positively correlated with the amount of grassland in the plot, as might be expected. In addition, the abundance of ground-nesting bees was highest in grazing regime 3 plots during the 1 year when those plots were grazed and had record numbers of species flowering. This finding is in agreement with other studies that found that floral abundance was the best predictor of pollinator abundance in pastures (Carvell 2002; Sjödin 2007). The results of our study suggest that grazing indirectly affected bee diversity by influencing the number of flowering species present at any time. That bee diversity increases with the number of flowering species seems natural, as different sizes and colors of flowers are likely to attract different bee species.

Other investigators examining grazing and the status of ground-nesting bees have obtained differing results. For example, Vulliamy et al. (2006) found that in Mediterranean habitats, intensive grazing increased bee abundance by increasing nesting sites and maintaining a diverse flora. In contrast, Gess and Gess (1993) and Sugden (1985) both found that grazing decreased bee abundance in their studies. Gess and Gess (1993) and Sugden (1985) measured the effects of grazing in semi-arid habitats in southern Africa and in California, respectively. Their results indicated that grazing animals trampled bees and compressed the ground making it less suitable for nest sites. In addition, the foraging done by grazing animals in these two studies increased the abundance of plants that were not attractive to bees. These three factors may have contributed to the decrease in bee abundance in these studies. Another variable that may influence bee numbers is the amount of moisture present in the habitat. In our study, the plots that were routinely grazed were often dry and lacked the abundance of flowers found in other plots. It is possible that the amount of moisture in the habitat may mediate the effects of grazing.

Other studies have documented higher numbers of cavity-nesting bees in small urban areas compared to larger, more natural habitats (Cane et al. 2006; Hinners 2008). We also expected to find that cavity-nesting bees would be more prevalent in the urban plots, but our study revealed no differences in the abundance of cavity-nesting bees in remote, urban or the Hayes plots. This finding may be due to the fact that cavity-nesting species made up a small percentage of all the bees collected.

Overall, our results indicate that the bee community in Boulder County grasslands is doing well and is comparable to the community that existed 100 years ago. While urban development was not a good predictor of insect abundance, the diversity indices indicated a trend of increased species diversity from urban, to remote, to the Hayes plots. Other environmental variables (e.g. square meters in the plot that were cultivated, grass, park, water, or wetland) were also not useful in predicting pollinator abundance. In contrast, the number of flowers in the plot and the grazing regimen were both correlated with bee numbers; bee diversity was highest in plots with many flowers and in plots that were grazed for 1 year. It appears that, similar to the findings of Sjödin (2007) and Carvell (2002), floral abundance is the best predictor of bee abundance.

Human population growth in Boulder County has increased greatly in the past century. Similar urban growth has been seen in many areas of the United States. In fact, urban development in the United States covers a land area greater than the combined area of all the state and national parks (McKinney 2002). Urban areas are characterized by sealed surfaces (pavement and buildings) and managed vegetation. Since urban areas continue to grow, the opportunity exists to plan developments that attract and encourage pollinators, native plants, and wildlife in general. Urban planning can incorporate native vegetation in such a way as to create corridors that connect urban parks with extensive plantings attractive to pollinators and other wildlife. Development of parks, office complexes, 
campuses, and home gardens with pollinators in mind can produce esthetically pleasing urban environments while preserving the diversity of flora and fauna. For example, several recent studies indicate that gardens and parks in urban areas can maintain diverse bee assemblages (McFrederick and LeBuhn 2006; Matteson et al. 2008), especially when native flowering species are planted (Frankie et al. 2002, 2005; Cane et al. 2006). As we gain an understanding of the resources needed by pollinators, we can actively try to incorporate them in the development of our urban areas to ensure that urban and suburban areas do not suffer losses in overall biodiversity.

Acknowledgments City of Boulder Open Space and Mountain Parks: funding via 2002 Small Grants Research Program, yearly permits; Virginia Scott, Cesar Nufio, PhD, University of Colorado Museum, University of Colorado; Sarah Hinners, University of Colorado; Torin Hultgren, University of Colorado; Betsy Forrest, PhD, University of Colorado; William Oliver, PhD, University of Colorado; Robert Minckley, $\mathrm{PhD}$, University of Rochester; National Science Foundation DEB grant-0515937 to CA Kearns; University of Colorado Baker Residential Academic Program undergraduate research assistants: Kira Krend, Christina Murphy, Geoffrey Garst, Keith Mitchell, Laura Waterbury, Tom Binet, Brian Miller, Daniel Veltri, Matthew Talarico, Lauren Mead, Shannon Madore, Taylor Whitten, Annie MacFadyen, Trent Tennyson, Steve McAllister; Undergraduate Research Opportunities Program, University of Colorado; Biological Sciences Initiative with funding from the Howard Hughes Medical Institute, University of Colorado; Garden owners: Cornelia and Jim Yarrington, Richard Kann, Lauren and Michael Kolbrener, Charlene and Michael Ryan, Jana and Tom Ward, Paul Barbin, Daniel and Pamela Decker, Richard Sigismund.

Open Access This article is distributed under the terms of the Creative Commons Attribution Noncommercial License which permits any noncommercial use, distribution, and reproduction in any medium, provided the original author(s) and source are credited.

\section{Appendix}

See, Table 3.

Table 3 Bee species collected

\begin{tabular}{|c|c|}
\hline Agapostemon & virescens \\
\hline Agapostemon & angelicus/texanus \\
\hline Andrena & claytonim $^{\mathrm{a}}$ \\
\hline Andrena & crataegi \\
\hline Andrena & cressonii(?) \\
\hline Andrena & gardineri(?) \\
\hline Andrena & sp 1 \\
\hline Andrena & sp 3 \\
\hline Andrena & sp 4 \\
\hline Andrena & sp 5 \\
\hline Andrena & sp 6 \\
\hline
\end{tabular}

Table 3 continued

\begin{tabular}{|c|c|}
\hline Andrena & sp 7 \\
\hline Andrena & sp 8 \\
\hline Andrena & sp 9 \\
\hline Anthidium & mогтопит \\
\hline Anthidium & porterae \\
\hline Anthidium & sp 1 \\
\hline Anthophora & montana \\
\hline Anthophora & smithii \\
\hline Anthophora & $\operatorname{sp} 2^{\mathrm{a}}$ \\
\hline Anthophora & sp 3 \\
\hline Apis & mellifera \\
\hline Augochlorella & striata \\
\hline Augochloropsis & metallica \\
\hline Augochloropsis & sumptuosa $a^{\mathrm{a}}$ \\
\hline Bombus & appositus \\
\hline Bombus & bifarius \\
\hline Bombus & centralis $^{\mathrm{a}, \mathrm{b}}$ \\
\hline Bombus & fervidus \\
\hline Bombus & flavifrons \\
\hline Bombus & fraternus \\
\hline Bombus & griseocollis \\
\hline Bombus & huntii \\
\hline Bombus & morrisonii \\
\hline Bombus & nevadensis \\
\hline Bombus & pensylvanicus \\
\hline Bombus & rufocinctus ${ }^{\mathrm{b}}$ \\
\hline Ceratina & nannula \\
\hline Ceratina & neomexicana \\
\hline Coelioxys & sayi \\
\hline Ceratina & sp 1 \\
\hline Colletes & phaceliae \\
\hline Diadasia & australis \\
\hline Diadasia & $\operatorname{diminuta}^{\mathrm{a}}$ \\
\hline Dianthidium & curvatum \\
\hline Dianthidium & pudicum, pudicum consimile \\
\hline Doerengiella (Triepeolus) & grandis $^{\mathrm{a}}$ \\
\hline Doerengiella (Triepeolus) & helanthi \\
\hline Doerengiella (Triepeolus) & sp 1 \\
\hline Epeolus & sp 1 \\
\hline Halictus & confusus \\
\hline Halictus & ligatus \\
\hline Halictus & rubicundus \\
\hline Halictus & tripartitus \\
\hline Heriades & carinata $^{\mathrm{a}}$ \\
\hline Hoplitis & pilosifrons \\
\hline Hoplitis & producta \\
\hline Hoplitis & spoliata $^{\mathrm{a}}$ \\
\hline Hylaeus & affinis \\
\hline Hylaeus & cressoni \\
\hline
\end{tabular}


Table 3 continued

\begin{tabular}{|c|c|}
\hline Hylaeus & episcopalis \\
\hline Hylaeus & mesillae \\
\hline Lasioglossum (Evylaeus) & cooleyi $i^{\mathrm{a}}$ \\
\hline Lasioglossum (Lasioglossum) & paraforbesii ${ }^{\mathrm{a}}$ \\
\hline Lasioglossum (Dialictus) & sisymbrii \\
\hline Lasioglossum & sp.2 \\
\hline Lasioglossum (Dialictus) & aberrans? \\
\hline Lasioglossum (Dialictus) & anomalus \\
\hline Lasioglossum (Dialictus) & imatatum \\
\hline Lasioglossum (Dialictus) & laevissimus \\
\hline Lasioglossum (Dialictus) & pruinosa \\
\hline Lasioglossum (Dialictus) & pruinosiformis \\
\hline Lasioglossum (Dialictus) & sp 1 \\
\hline Lasioglossum (Dialictus) & sp 2 \\
\hline Lasioglossum (Dialictus) & sp 3 \\
\hline Lasioglossum (Dialictus) & sp 4 \\
\hline Lasioglossum (Dialictus) & sp 5 \\
\hline Lasioglossum (Evylaeus) & $\operatorname{sp} 1^{\mathrm{a}}$ \\
\hline Lasioglossum (Evylaeus) & $\operatorname{sp} 2^{\mathrm{a}}$ \\
\hline Lithurge & apicalis \\
\hline Megachile & brevis \\
\hline Megachile & fortis \\
\hline Megachile & latimanus \\
\hline Megachile & manifesta $^{\mathrm{a}}$ \\
\hline Megachile & montivaga \\
\hline Megachile & parallela \\
\hline Megachile & sexdunata $^{\mathrm{a}}$ \\
\hline Megachile & sp 1 \\
\hline Megachile & $\operatorname{sp} 2^{\mathrm{a}}$ \\
\hline Megachile & sp 3 \\
\hline Megachile & $\operatorname{sp} 4^{\mathrm{a}}$ \\
\hline Megachile & subexilis \\
\hline Megachile & wootoni \\
\hline Melisodes & tristis \\
\hline Melissodes & agilis \\
\hline Melissodes & bimaculatus $^{\mathrm{b}}$ \\
\hline Melissodes & coreopsis \\
\hline Melissodes & grindelia? \\
\hline Melissodes & menuachus \\
\hline Nomada & $\operatorname{sp~} 1^{\mathrm{a}}$ \\
\hline Osmia & atrocyanea \\
\hline Osmia & bruneri \\
\hline Osmia & cordata \\
\hline Osmia & nanula $^{\mathrm{a}}$ \\
\hline Perdita & rectangulata \\
\hline Perdita & sp 1 \\
\hline Sphecodes & eustictus \\
\hline Sphecodes & sp 1 \\
\hline Sphecodes & $\operatorname{sp} 2^{a, b}$ \\
\hline
\end{tabular}

Table 3 continued

\begin{tabular}{ll}
\hline Sphecodes & sp 3 \\
Stelis & monticola \\
Svastra & obliqua \\
\hline
\end{tabular}

${ }^{a}$ Pan trapped only

b Gardens only

\section{References}

Allen-Wardell G, Bernhardt P, Bitner R, Burquez A, Buchmann S, Cane J, Cox P, Dalton V, Feinsinger P, Ingram M, Inouye D, Jones C, Kennedy K, Kevan P, Koopowitz H, Medellin R, MedellinMorales S, Nabham G, Pavlik B, Tepedino V, Torchio P, Walker S (1998) The potential consequences of pollinator declines on the conservation of biodiversity and stability of food crop yields. Conserv Biol 12:8-17. doi:10.1046/j.1523-1739.1998.97154.x

Bañkowska R (1980) Fly communities of the family Syrphidae in natural and anthropogenic habitats of Poland. Memorab Zool 33:3-93

Bañkowska R (1981) Hover flies (Diptera, Syrphidae) of Warsaw and Mazovia. Memorab Zool 35:57-78

Bennett BC (1997) Vegetation on the City of Boulder Open Space grasslands. $\mathrm{PhD}$ dissertation, University of Colorado, $\mathrm{CO}$

Berry ME, Bock CE, Haire SL (1998) Abundance of diurnal raptors on open space grasslands in an urbanized landscape. Condor 100:601-608. doi:10.2307/1369742

Bock CE, Bock JH (1994) A field guide to City of Boulder Open Space grassland biodiversity plots. Unpublished report. University of Colorado, $\mathrm{CO}$

Bock CE, Bock JH, Bennett BC (1995) The avifauna of remnant tallgrass prairie near Boulder, Colorado. Prairie Nat 27:147-157

Bock CE, Bock JH, Bennett BC (1999) Songbird abundance in grasslands at a suburban interface on the Colorado high plains. Stud Avian Biol 19:131-136

Bock CE, Vierling KT, Haire SL, Boone JD, Merkl WW (2002) Patterns of rodent abundance on open-space grasslands in relation to suburban edges. Conserv Biol 16:1653-1658. doi:10.1046/ j.1523-1739.2002.01291.x

Bolger DT, Suarez AV, Crooks KR, Morrison SA, Case TJ (2000) Arthropods in urban habitat fragments in southern California: area, age, and edge effects. Ecol Appl 10:1230-1248. doi:10.1890/ 1051-0761(2000)010[1230:AIUHFI]2.0.CO;2

Brose U, Martinez ND (2004) Estimating the richness of species with variable mobility. Oikos 105:292-300. doi:10.1111/j.0030-1299. 2004.12884.x

Buchmann SL, Nabhan GP (1996) The forgotten pollinators. Island, Washington

Cane JH (2005a) Bees, pollination, and the challenges of sprawl. In: Johnson EA, Klemens MW (eds) Nature in fragments: the legacy of sprawl. Columbia University Press, New York, pp 109-124

Cane JH (2005b) Pollination potential of the bee Osmia aglaia for cultivated red raspberries and blackberries (Rubus:Rosaseae). HortScience 40:1705-1708

Cane JH, Tepedino VJ (2001) Causes and extent of declines among native North American invertebrate pollinators: detection, evidence, and consequences. Conserv Ecol 5(1):1. Online: http://www.consecol. org/vol5/iss1/art1

Cane JH, Minckley R, Roulston T, Kervin L, Willliams NM (2006) Multiple response of desert bee guild (Hymenoptera: Apiformes) 
to urban habitat fragmentation. Ecol Appl 16:632-644. doi: 10.1890/1051-0761(2006)016[0632:CRWADB]2.0.CO;2

Carvell C (2002) Habitat use and conservation of bumblebees (Bombus spp.) under different grassland management regimes. Biol Conserv 103:33-49. doi:10.1016/S0006-3207(01)00114-8

City of Boulder Open Space and Mountain Parks (2004) Open space and mountain parks vegetation maps. Copyright City of Boulder, Boulder

City of Boulder Open Space and Mountain Parks (2006) A history of boulder's open space \& mountain parks. Online: http://www. bouldercolorado.gov/index 2.php?option $=$ com_content\&do_pdf= $1 \& \mathrm{id}=1167$. Accessed July 2007

Cockerell TDA (1907) The bees of Boulder County, Colorado. Univ Colo Stud IV(4), Boulder

Collinge SK (2001) Effects of grassland fragmentation on insect species loss, colonization, and movement patterns. Ecology 81:2211-2226

Collinge SK, Prudic KL, Oliver JC (2003) Effects of local habitat characteristics and landscape context on grassland butterfly diversity. Conserv Biol 17:178-187. doi:10.1046/j.1523-1739. 2003.01315.x

Colwell RK (2005) EstimateS: statistical estimation of species richness and shared species from samples. Version 7.5 Persistent URL: purl.oclc.org/estimates

Craig DP, Bock CE, Bennett BC, Bock JH (1999) Habitat relationships among grasshoppers (Orthoptera: Acrididae) at the western limit of the Great Plains in Colorado. Am Midl Nat 142:314-327. doi: 10.1674/0003-0031(1999)142[0314:HRAGOA]2.0.CO;2

ESRI software (2004) ArcGIS. Online: http://www.esri.com/

Frankie GW, Thorp RW, Schindler MH, Ertter B, Przybylski M (2002) Bees in Berkeley? Fremontia 30:50-61

Frankie GW, Thorp RW, Schindler M, Hernandez J, Ertter B, Rizzardi M (2005) Ecological patterns of bees and their host ornamental flowers in two northern California cities. J Kans Entomol Soc 78:227-246

French K, Major R, Hely K (2005) Use of native and exotic garden plants by suburban nectarivorous birds. Biol Conserv 121:545-559

Gathmann A, Tscharntke T (2002) Foraging ranges of solitary bees. J Anim Ecol 71:757-764

Gess FW, Gess SK (1993) Effects of increasing land utilization on species representation and diversity of aculeate wasps and bees in the semi-arid areas of southern Africa. In: LaSalle J, Gauld ID (eds) Hymenoptera and biodiversity. CAB International, Wallingford, pp 83-113

Haire SL, Bock CE, Cadea BS, Bennett BC (2000) The role of landscape and habitat characteristics in limiting abundance of grassland nesting songbirds in an urban open space. Landsc Urban Plan 48:65-82

Hellman JJ, Fowler GW (1999) Bias, precision, and accuracy of four measures of species richness. Ecol Appl 9:824-834

Herrera CM (1988) Variation in mutualisms: the spatio-temporal mosaic of a pollinator assemblage. Biol J Linn Soc 35:95-125

Hinners SJ (2008) Pollinators in an urbanizing landscape: effects of suburban sprawl on a grassland bee assemblage. $\mathrm{PhD}$ dissertation. University of Colorado, $\mathrm{CO}$

Hughes JB, Daily GC, Ehrlich PR (2000) Conservation of insect diversity: a habitat approach. Conserv Biol 14:1788-1797

Inoue T, Kato M, Kakutani T, Suka T, Itino T (1990) Insect-flower relationship in the temperate deciduous forest of Kibune, Kyoto: an overview of the flowering phenology and the seasonal pattern of insect visits. Contrib Biol Lab Kyoto Univ 27:377-463

Johnson EA, Klemens MW (2005a) Nature in fragments: the legacy of sprawl. Columbia University Press, New York, pp ix-xii

Johnson EA, Klemens MW (2005b) The impacts of sprawl on biodiversity. In: Johnson EA, Klemens MW (eds) Nature in fragments: the legacy of sprawl. Columbia University Press, New York, pp 18-56

Kakutani T, Inoue T, Kato M, Ichihashi H (1990) Insect-flower relationship in the campus of Kyoto University, Kyoto: an overview of the flowering phenology and the seasonal pattern of insect visits. Contrib Biol Lab Kyoto Univ 27:465-521

Kato M, Kakutani T, Inoue T, Itino T (1990) Insect-flower relationship in the primary beech forest of Ashu, Kyoto: an overview of the flowering phenology and the seasonal pattern of insect visits. Contrib Biol Lab Kyoto Univ 27:309-375

Kearns CA, Inouye DW, Waser N (1998) Endangered mutualisms: the conservation biology of plant-pollinator interactions. Annu Rev Ecol Syst 29:83-112

Kruess A, Tscharntke T (2002) Grazing intensity and the diversity of grasshoppers, butterflies, and trap-nesting bees and wasps. Conserv Biol 16:1570-1580

LeBuhn G, Griswold T, Minckley R (2003) A standardized method for monitoring bee populations - the bee inventory plot. Online: http://online.sfsu.edu/ beeplot/

Magurran AE (2006) Measuring biological diversity. Blackwell, Malden

Matteson KC, Ascher JS, Langellotto GA (2008) Bee richness and abundance in New York City urban gardens. Ann Entomol Soc Am 101(1):140-150

McFrederick QS, LeBuhn G (2006) Are urban parks refuges for bumble bees Bombus spp. (Hymenoptera: Apidae)? Biol Conserv 129:372-382

McGeoch MA, Chown SL (1997) Impact of urbanization on a gallinhabiting Lepidoptera assemblage: the importance of reserves in urban areas. Biodivers Conserv 6:979-993

McIntyre NE, Rango J, Fagan WF, Faeth SH (2001) Ground arthropod community structure in a heterogeneous urban environment. Landsc Urban Plan 52:257-274

McKinney ML (2002) Urbanization, biodiversity, and conservation. BioSci 52:883-890

Minckley RL, Cane JH, Kervin L, Roulston TH (1999) Spatial predictability and resource specialization of bees (Hymenoptera: Apoidea) at a superabundant, widespread resource. Biol J Linnean Soc 67:119-147

O'Toole C (1993) Diversity of native bees and agroecosystems. In: LaSalle J, Gauld ID (eds) Hymenoptera and biodiversity. CAB International, Wallingford, pp 169-196

Osborne JL, Corbet SA (1994) Managing habitats for pollinators in farmland. Asp Appl Biol 40:207-215

Osborne JL, Williams IH, Corbet SA (1991) Bees, pollination and habitat change in the European Community. Bee World 72:99-116

Richards AJ (1986) Plant breeding systems. George Allen and Unwin, London

Roubik DW (2001) Ups and downs in pollinator populations: when is there a decline? Conserv Ecol 5:2. Online: http://www.consecol. org/vol5/iss 1/art2

SAS Institute Inc. (2002-2003) SAS 9.1. SAS Institute Inc., Cary

Sjödin NE (2007) Pollinator behavioural responses to grazing intensity. Biodivers Conserv 16:2103-2121

Steffan-Dewenter I, Munzenberg U, Burger C, Thies C, Tscharntke T (2002) Scale-dependent effects of landscape context on three pollinator guilds. Ecology 83:1421-1432

Stewart R (2005-2006) About Boulder County parks and open space. Boulder County Parks and Open Space. Online: www.co. boulder.co.us/openspace/. Accessed July 2007

Sugden E (1985) Pollinators of Astragalus monoensis barneby (Fabaceae) - new host records-potential impact of sheep grazing. Gt Basin Nat 45:299-312

Tomassi D, Miro A, Higo HA, Winston ML (2004) Bee diversity and abundance in an urban setting. Can Entomol 136:851-869 
Turner WR, Nakamura T, Dinetti M (2004) Global urbanization and the separation of humans from nature. BioSci 54:585-590

US Dept of Agriculture (2007) Arapaho \& Roosevelt National Forests Pawnee National Grassland, Boulder Ranger District. Online: http://www.fs.fed.us/r2/arnf/about/organization/brd/index.shtml

USGS (1999) Land use and land cover data. Rocky Mountain Mapping center, Denver

Vulliamy B, Potts SG, Willmer PG (2006) The effect of cattle grazing on plant-pollinator communities in a fragmented Mediterranean landscape. Oikos 114:529-543
Williams NM, Minckley RL, Silveira FA (2001) Variation in native bee faunas and its implications for detecting community changes. Conserv Ecol 5:7. Online: http://www.consecol.org/ vol5/iss $1 /$ art7

Zanette LRS, Martins RP, Ribeiro SP (2005) Effects of urbanization on Neotropical wasp and bee assemblages in a Brazilian metropolis. Landsc Urban Plan 71:105-121 